Artigo Especial

\title{
The history of the Diego blood group
}

Pedro C. Junqueira ${ }^{1}$

Lilian Castilbo ${ }^{2}$

\begin{abstract}
Diego blood group initially, because it appeared to be rare, was considered as a family or 'private factor'. With further investigation, it was possible to trace this blood group from an individual family in Venezuela to the Indians across the continent of America and eventually to the Mongolian race in Asia. This review article follows the developments over the years and the bistory of the Diego blood group.

Rev.bras.hematol.hemoter.,2002,24(1):15-23
\end{abstract}

Keywords: Diego, blood group, history

\section{Diego as a "Private Factor"}

In 1953, Miguel Larysse and his co-workers Túlio Arends and R. Dominguez Sisco (from the Maternidad Concepcíon, Caracas) at the Centro de Investigaciones del Banco de Sangue de Caracas studied a serum from a full term male infant who appeared at birth to be clinically and hematologically normal but at that time the billirrubin determination was not carried out. Jaundice was evident after 12 hours, it became increasingly severe and the infant expired at three days. The direct antiglobulin test carried out on the newborn's red blood cells was positive. Blood specimens of the Rh-positive mother and her Rhgroup compatible infant were sent to Philip Levine at his consultation service from Ortho Research Foundation (Raritan, New Jersey) and both samples arrived in excellent conditions in June. Although the infant's red cells were strongly "coated", no antibody was demonstrable in the maternal serum when it was tested with an extensive panel of selected cells, which, did not include the father's red blood cells. As ABO and
Rh incompatibility was excluded, the occurrence of a "low-incidence" blood factor with its corresponding antibody was suspected.

On October $26^{\text {th }}, 1953$, the father of the dead infant visited Levine in New York. At this time his red blood cells were tested against the maternal serum and a strong agglutination reaction was found. Levine and the father agreed with the name of the blood factor as Diego $\left(\mathrm{Di}^{\mathrm{a}}\right)$.

Levine also demonstrated that $\mathrm{Di}^{\mathrm{a}}$ was not identical with two other previously recognized low-incidence blood factors associated with cases of hemolytic disease of the newborn named as $\mathrm{Mi}^{\mathrm{a}}$ and $\mathrm{Be}^{\mathrm{a}}$.

The $\mathrm{Di}^{\mathrm{a}}$ antibody was described as one of the six antibodies named as "Private" or "Family Blood Factors" (1). In this paper, they also reported that this antibody was "currently under investigation" at the Ortho Research Foundation and that it caused hemolytic disease and had negative reactions with 200 random white red blood cells tested. Table 1 shows the typing of red cell antigens in selected members of the Diego family.

1 - Honorary president of the Brazilian Society of Hematology and Hemotherapy, member of the Brazilian Academy of Medicine

2 - PhD, Researcher and Consultant in Immunohematology, Hemocentro, Unicamp

Correspondência para: Pedro C. Junqueira

R. Prudêncio de Moraes, 985 - apto 104 - Rio de Janeiro - RJ - CEP: 22420-041 - fone: (21) 2522-9951 
Table 1 - Typing of red cell antigens in selected members of the Diego Family

\begin{tabular}{|c|c|c|c|c|c|c|c|c|c|c|}
\hline & $\mathrm{ABO}$ & $\mathrm{Rh}$ & $\mathrm{MN}$ & Ss & $\mathrm{Kk}$ & $\mathrm{Fy}^{\mathrm{a}}$ & $\mathrm{Jk}^{\mathrm{a}} / \mathrm{Jk}^{\mathrm{b}}$ & $\mathrm{Le}^{\mathrm{a}}$ & $\mathrm{P}$ & $\mathrm{Di}^{\mathrm{a}}$ \\
\hline I-1 & $\mathrm{O}$ & Cde/cde & $\mathrm{N}$ & nt & $\mathrm{nt}$ & nt & $\mathrm{nt}$ & nt & nt & + \\
\hline $\mathrm{I}-2$ & A & dCe/dce & $\mathrm{N}$ & nt & $\mathrm{nt}$ & nt & nt & $\mathrm{nt}$ & $\mathrm{nt}$ & + \\
\hline II-1 & $\mathrm{O}$ & dcE/dce & $\mathrm{N}$ & $\mathrm{nt}$ & $\mathrm{nt}$ & nt & $\mathrm{nt}$ & $\mathrm{nt}$ & $\mathrm{nt}$ & 0 \\
\hline II-2 & $\mathrm{O}$ & dcE/dce & $\mathrm{MN}$ & SS & $\mathrm{Kk}$ & 0 & $\mathrm{Jk}^{\mathrm{a}} \mathrm{Jk}^{\mathrm{b}}$ & 0 & 0 & + \\
\hline II-3 & $\mathrm{O}$ & Dce/dce & $\mathrm{M}$ & Ss & $\mathrm{Kk}$ & + & $\mathrm{Jk}^{\underline{a}} \mathrm{Jk}^{\mathrm{b}}$ & 0 & + & 0 \\
\hline II-4 & $\mathrm{O}$ & Dce/dce & $\mathrm{N}$ & nt & nt & $\mathrm{nt}$ & $\mathrm{Nt}$ & $\mathrm{nt}$ & nt & 0 \\
\hline III-1 & $\mathrm{O}$ & Dce/dcE & M & Ss & $\mathrm{Kk}$ & 0 & $\mathrm{Jk}^{\underline{\mathrm{a}}} \mathrm{Jk}^{\mathrm{b}}$ & 0 & 0 & 0 \\
\hline III-3 & $\mathrm{O}$ & dcE/dce & $\mathrm{MN}$ & Ss & $\mathrm{Kk}$ & + & $\mathrm{Jk}^{\mathrm{a}} ?$ & 0 & 0 & 0 \\
\hline III-5 & $\mathrm{O}$ & dcE/dce & $\mathrm{M}$ & SS & $\mathrm{Kk}$ & + & $\mathrm{Jk}^{\mathrm{b}} \mathrm{Jk}^{\mathrm{b}}$ & 0 & + & + \\
\hline III-6 & $\mathrm{O}$ & $\mathrm{DCe} / \mathrm{DCe}$ & $\mathrm{MN}$ & SS & $\mathrm{Kk}$ & + & $\mathrm{Jk}^{\underline{\mathrm{a}}} \mathrm{jk}^{\mathrm{b}}$ & 0 & + & 0 \\
\hline III-7 & $\mathrm{O}$ & dce/dce & $\mathrm{M}$ & Ss & $\mathrm{Kk}$ & + & $\mathrm{Jk}^{\mathrm{a}} \mathrm{Jk}^{\mathrm{b}}$ & 0 & 0 & 0 \\
\hline III-9 & $\mathrm{O}$ & Dce/dce & $\mathrm{nt}$ & nt & nt & $\mathrm{nt}$ & $\mathrm{Nt}$ & $\mathrm{nt}$ & nt & + \\
\hline III-10 & $\mathrm{O}$ & ddE/dce & $\mathrm{M}$ & Ss & $\mathrm{Kk}$ & 0 & $\mathrm{Jk}^{\mathrm{a}} \mathrm{J} \mathrm{k}^{\mathrm{b}}$ & 0 & + & + \\
\hline III-11 & $\mathrm{O}$ & dce/dce & M & Ss & $\mathrm{Kk}$ & + & $\mathrm{Jk}^{\mathrm{b}} \mathrm{Jk}^{\mathrm{b}}$ & 0 & + & + \\
\hline IV-7 & $\mathrm{O}$ & $\mathrm{DCe} / \mathrm{dcE}$ & $\mathrm{MN}$ & Ss & $\mathrm{Kk}$ & + & $\mathrm{Jk}^{\mathrm{a}} \mathrm{J} \mathrm{k}^{\mathrm{b}}$ & 0 & 0 & + \\
\hline IV-8 & $\mathrm{O}$ & $\mathrm{DCe} / \mathrm{dcE}$ & $\mathrm{MN}$ & Ss & $\mathrm{Kk}$ & 0 & $\mathrm{Jk}^{\mathrm{a}} \mathrm{J} \mathrm{k}^{\mathrm{b}}$ & + & + & + \\
\hline IV-9 & $\mathrm{O}$ & DCe/dce & $\mathrm{nt}$ & nt & nt & $\mathrm{nt}$ & $\mathrm{nt}$ & $\mathrm{nt}$ & nt & + \\
\hline IV-10 & $\mathrm{O}$ & DCe/dce & $\mathrm{nt}$ & $\mathrm{nt}$ & $\mathrm{nt}$ & $\mathrm{nt}$ & $\mathrm{nt}$ & nt & $\mathrm{nt}$ & 0 \\
\hline
\end{tabular}

$n t=$ not tested

\section{Diego as an "Indian Factor"}

In 1955, the mother of the first documented $\mathrm{Di}^{\mathrm{a}}$ antibody carrier consulted Layrisse about a new pregnancy, which permitted further and more extensive tests in Venezuela and at Raritan, New Jersey. Layrisse and collaborators studying four generations of the original Diego family, noticed that the third and fourth generations seemed to be Caucasoid but their skins were a little darkbrown. However, the members of the second generation and the great grandmother in the first generation had a dark-brown skin and they seemed to be of Mongolian origin. Taking into account this observation, they started to observe the physical characteristics of a population from different countries with 286 individuals who had been tested with an anti$\mathrm{Di}^{\mathrm{a}}$ serum by the indirect antiglobulin test. The frequencies of positive results found in these populations were:

\begin{tabular}{|cc|}
\hline $\begin{array}{c}\text { Population } \\
\text { tested }\end{array}$ & $\begin{array}{c}\text { Frequencies of } \\
\mathbf{D i}^{\mathbf{a}} \text { found }\end{array}$ \\
\hline Caracas & $2.26 \%$ \\
Barcelona & $3.28 \%$ \\
Carib Indian & $35.54 \%$ \\
Arawaka Indian & $5.26 \%$ \\
Curiepe mixed Negro & $7.33 \%$ \\
\hline
\end{tabular}

From these findings Layrisse et al., 1955 (2), concluded that it was evident that the Diego Factor was not restricted to a single family, and could be placed among the relatively high incidence blood group systems in Venezuela and probably in South America, with apparently genetic, anthropologic and clinical significances. They also commented that since the Diego terminology was meaningless and this factor had probably some anthropological implications it should be changed to a more expressive one like "Indian Factor". About this comment we must remember that Chown and Lewis (Nature, 1953) said that what appears to be a rare, private 
or family antigen in one population might be fairly frequent in another one, and so Layrisse was right.

In 1955, Dr Jean Dausset, a French immunologist, later awarded the Nobel Prize (1980), after working with Layrisse in Caracas, came to Rio de Janeiro to visit me because I was studying the Brazilians Indians. At the time, Dr Dausset brought me a sample of the Diego serum and this serum turned out to be very important to me. In that year we had the opportunity to test two Brazilian Indian groups with the anti-Diego serum using the indirect antiglobulin test: the Carajas living in Santa Izabel, Bananal Island, State of Mato Grosso and the Kaingaques living in a reservation near Palmas, State of Paraná. Thirteen (36\%) of the red blood samples from the Carajas tested and $22(46 \%)$ of the Kaingaques samples tested gave positive reactions with the anti-Diego serum. We had also the opportunity to test 200 red blood samples from true Black donors from the Rio de Janeiro Municipal Blood Bank that showed negative results with the antiDiego serum. We sent our results to Layrisse, in Caracas and to Levine, in Raritan. We had our paper published in Nature, volume 17 on page 41 (3). Levine et al. published their paper in this same volume of the Nature Journal on page 40 (4).

Table 2 shows the incidence of the $\mathrm{Di}^{\mathrm{a}}$ antigen in different Indian populations.

\section{Diego as a "Mongolian Factor"}

In 1956, in a paper published in the Nature Journal (5), Layrisse and Arends stated: "Since the Indians of the American continent are considered to be anthropological related to the Mongolian people of the old world, we decided to investigate the incidence of the Diego Factor in other available representative Asians living in Venezuela". They tested 100 unrelated males from Canton (China), living in Venezuela, and detected 5 Diego positive individuals ( $5 \%$ of the Chinese tested). They also tested sixty-five unrelated Japanese and found 8 Diego positive subjects (12.5\% of the Japanese tested) (6). These findings indicated that the Diego factor was not restricted to South America and suggested that this antigen was a Mongolian rather than an Indian factor.

In the same year, Lewis et al., (7) showed that the Diego antigen was found to be present in 16 of 148 unrelated Chippewa Indians from North Minnesota and in 6 of 77 unrelated Japanese from Winnipeg. This finding suggested that Diego might be an Asiatic characteristic.

In 1957, Levine and Robinson (8) said that studies carried out by Layrisse and his colleagues on the Diego blood factor in other populations including the Brazilian Indians carried out by Junqueira et al. (3), apparently suspected that the Diego factor could be Mongolian in its origin. Further, they concluded that the term Indian for the Diego blood factor was not appropriate.

Levine and Robinson, 1957 (8) also demonstrated that the $\mathrm{Di}^{\mathrm{a}}$ antigen was genetically independent from other 15 low incidence factors and from four high incidence factors previously recognized. Furthermore, Layrisse, Sanger and Race, 1959 (9) using evidence from the literature and from nine new families studied, showed that the $\mathrm{Di}^{\mathrm{a}}$ antigen had no links with most of the established blood group systems.

Many papers showing the distribution of the $\mathrm{Di}^{\mathrm{a}}$ antigen considered that it was essentially a Mongolian characteristic, absent in Whites , Blacks, Australian aborigines and other populations (10-39). Table 3 shows the incidence of the $\mathrm{Di}^{\mathrm{a}}$ antigen in the Chinese and Korean populations.

The book named "The distribution of Human Blood Groups and other polymorphisms" (Mourant et al., 1976) (40) is considered the best one to show the early worldwide race distribution of $\mathrm{Di}^{\mathrm{a}}$.

In 1967, thirteen years after the detection of the anti-Di $\mathrm{i}^{\mathrm{a}}$, Thompson, Childers and Hatcher identified the anti-Dib (41). As the phenotype $\mathrm{Di}(\mathrm{a}-\mathrm{b}-)$ has not been reported yet, we may assume that only two alleles $\left(\mathrm{Di}^{\mathrm{a}}\right.$ and $\left.\mathrm{Di}^{\mathrm{b}}\right)$ control the Diego blood group system.

Both antibodies, anti-Di ${ }^{\mathrm{a}}$ and anti- $\mathrm{Di}^{\mathrm{b}}$ are 
Table 2 - Incidence of the D $i^{\underline{a}}$ antigen in different indian populations

\begin{tabular}{|c|c|c|c|c|c|}
\hline Population & Indians & $\begin{array}{c}\text { Number } \\
\text { tested }\end{array}$ & $\begin{array}{c}\text { Number } \\
\operatorname{Di}\left(a^{+}\right)\end{array}$ & $\begin{array}{l}\text { Percent } \\
\text { Di(a+) }\end{array}$ & Reference \\
\hline \multirow{3}{*}{ Venezuela } & $\begin{array}{c}\text { Carib } \\
\text { (Cachama) }\end{array}$ & 121 & 43 & 35.6 & Layrisse et al,1955 \\
\hline & $\begin{array}{l}\text { Carib } \\
\text { (Aribi) }\end{array}$ & 49 & 7 & 14.3 & \\
\hline & $\begin{array}{l}\text { Arawako } \\
\text { (Guajiros) }\end{array}$ & 152 & 8 & 5.3 & \\
\hline \multirow[t]{2}{*}{ Brazil } & $\begin{array}{c}\text { Carajas } \\
\text { (São Domingos) }\end{array}$ & 36 & 13 & 36.1 & \multirow[t]{2}{*}{ Junqueira et al., 1956} \\
\hline & $\begin{array}{c}\text { Kaingangues } \\
\text { (São Domingos) }\end{array}$ & 48 & 22 & 45.8 & \\
\hline North Americans & Chippewa & 148 & 16 & 10.8 & Lewis et al., 1956 \\
\hline Mexico & & 152 & 31 & 20.4 & Salazar et al., 1959 \\
\hline USA & Penobscots & 244 & 20 & 8.0 & Allen et al., 1960 \\
\hline \multirow[t]{3}{*}{ Brazil } & $\begin{array}{c}\text { Xavantes } \\
\text { (São Domingos) }\end{array}$ & 78 & 24 & 30.4 & Neal et al., 1964 \\
\hline & $\begin{array}{c}\text { Xavantes } \\
\text { (São Marcos) }\end{array}$ & 289 & 78 & 27.0 & \multirow[t]{2}{*}{ Gershowitz et al., 1967} \\
\hline & $\begin{array}{c}\text { Xavantes } \\
\text { (Simoes Lopes) }\end{array}$ & 171 & 62 & 36.3 & \\
\hline Guatemala & Mayan Indians & 255 & 57 & 22.3 & Cann et al., 1968 \\
\hline Mexican Americans & & 1685 & 172 & 10.2 & Edwards-Moulds et al., 1986 \\
\hline USA & Chippewa & 119 & 9 & 7.0 & Lee et al., 1990 \\
\hline Venezuela & Caracas & 65 & 8 & 12.3 & Layrisse et al., 1956 \\
\hline Canada & Winnepeg & 77 & 6 & 7.8 & Lewis et al., 1956 \\
\hline \multirow{6}{*}{ Japan } & Tokio & 88 & 2 & 2.3 & Furuhata et al., 1957 \\
\hline & Kumamoto & 153 & 12 & 7.8 & Ueno et al., 1957 \\
\hline & Jumma & 500 & 16 & 3.2 & Masakis et al., 1959 \\
\hline & Tokio & 146 & 6 & 4.1 & \multirow[t]{2}{*}{ Yokoyama et al., 1960} \\
\hline & Kumamoto & 227 & 17 & 7.5 & \\
\hline & Hiroshima & 309 & 25 & 8.1 & Tsuchiya et al., 1964 \\
\hline Brazil & Rio de Janeiro & 207 & 13 & 6.7 & Cerqueira et al., 1968 \\
\hline
\end{tabular}

responsible for the hemolytic disease of the newborn and for hemolytic transfusion reactions (42). Due to the composition of our population, and supported by studies showing that $3.6 \%$ of the multi-transfused patients in Brazil have anti$\mathrm{Di}^{\mathrm{a}}$ (43) the Brazilian red cell panels used for antibody screening ought to include a $\mathrm{Di}(\mathrm{a}+)$.

In 1975, Race and Sanger (42) said in the last edition $\left(6^{\text {th }}\right)$ of their book: "The Venezuelan discovery of $\mathrm{Di}^{\mathrm{a}}$ will make an outstanding contribution to the anthropology of the Mongolian world". 
3 - Incidence of the Diego antigen in the chinese and korean populations

\begin{tabular}{|l|c|c|c|c|c|}
\hline Population & Chinese & $\begin{array}{c}\text { Number } \\
\text { tested }\end{array}$ & $\begin{array}{c}\text { Number } \\
\text { Di(a+) }\end{array}$ & $\begin{array}{c}\text { Percent } \\
\text { Di(a+) }\end{array}$ & Reference \\
\hline Venezuela & Canton & 100 & 5 & 5.0 & Layrisse et al., 1956 \\
\hline Taiwan & Fukein and Canton & 1000 & 32 & 3.2 & Lin-Chu et al., 1988 \\
\hline Korea & Seoul & 227 & 17 & 6.1 & Won et al., 1960 \\
\hline
\end{tabular}

Table 4 - Antigen assigned to Diego blood group system by the ISBT Nomenclature (Daniels et al., 2001)

\begin{tabular}{|c|c|c|c|}
\hline System & Number & Symbol & Amino Acid Substitution \\
\hline 010DI & 0100001 DI 1 & $\mathrm{Di}^{\underline{\mathrm{a}}}$ & Leu 854 \\
\hline 010DI & 0100002 DI 2 & $\mathrm{Di}^{\mathrm{b}}$ & Pro 854 \\
\hline 010DI & 0100003 DI 3 & $\mathrm{Wr} \mathrm{r}^{\mathrm{a}}$ & Lys 658 \\
\hline $010 \mathrm{DI}$ & 010004 DI 4 & $\mathrm{Wr}^{\mathrm{b}}$ & Glu658 \\
\hline 010DI & 0100005 DI 5 & $\mathrm{Wd}^{\underline{a}}$ & Val 557 Met \\
\hline 010DI & 0100006 DI 6 & $\mathrm{Rb}^{\mathrm{a}}$ & Pro 548 Leu \\
\hline 010DI & 0100007 DI 7 & WARR & Thr 552 lle \\
\hline 010DI & 0100008 DI 8 & ELO & Arg $432 \operatorname{Trp}$ \\
\hline 010DI & 0100009 DI 9 & Wu & Gly 565 Ala \\
\hline 010DI & 0100010 DI 10 & $\mathrm{Bp} \mathrm{p}^{\mathrm{a}}$ & Asm 569 Lys \\
\hline 010DI & 0100011 DI 11 & $\mathrm{Mo}^{\mathrm{a}}$ & Arg 656 His \\
\hline 010DI & 0100012 DI 12 & $\mathrm{Hg}^{\mathrm{a}}$ & Arg 656 Cys \\
\hline 010DI & 0100013 DI 13 & $\mathrm{Ug}^{\mathrm{a}}$ & Tyr 555 His \\
\hline 010DI & 0100014 DI 14 & $\mathrm{Sw}^{\mathrm{a}}$ & Arg 646 Gln \\
\hline 010DI & 0100015 DI 15 & BOW & Pro 561 Ser \\
\hline 010DI & 0100016 DI 16 & NFLD & $\begin{array}{l}\text { Glu } 429 \text { Asp } \\
\text { Pro } 561 \mathrm{Ala}\end{array}$ \\
\hline 010DI & 0100017 DI 17 & $\mathrm{Jn}^{\underline{\mathrm{a}}}$ & Pro 566 Ser \\
\hline 010DI & 0100018 DI 18 & KREP & Pro 566 Ala \\
\hline 010DI & 0100019 DI 19 & Tra & Lys551Asn \\
\hline $010 \mathrm{DI}$ & 0100020 DI 20 & Fra & Glu480Lys \\
\hline 010DI & 0100021 DI 21 & SW1 & Arg646Trp \\
\hline
\end{tabular}

\section{The Diego blood group system}

The Diego blood group system is a rapidly expanding system and today it consists of two pairs of antithetical antigens $\left(\mathrm{Di}^{\mathrm{a}}\right.$ and $\mathrm{Di}^{\mathrm{b}}$, and $\mathrm{Wr}^{\mathrm{a}}$ and $\mathrm{Wr}^{\mathrm{b}}$ ) and 17 low incidence antigens (44) (Table 4).

Spring et al., in 1992 (45) recognized an association between band 3 (anion exchange 1 - AE1), the most abundant integral protein of the red blood cell (RBC) membrane, and the Diego blood group system. They found by SDSPAGE that $\mathrm{Di}(\mathrm{a}+)$ red cells always have band 3 variant Memphis, although not all band 3
Memphis red cells are $\operatorname{Di}\left(\mathrm{a}^{+}\right)$. This observation led to the investigation of band 3 from red cells of known Diego blood group in order to ascertain whether the expression of the $\mathrm{Di}^{\mathrm{a}}$ antigen is linked to band 3 Memphis, and to define the molecular basis of this variant.

In 1993, the Diego blood group locus was assigned to chromosome 17 by Zelinski et al., (46) and in 1994, Bruce et al. (47) showed by H DIDS (4,4' -diisothiocyanato-2,2' dihydrostibene disulfonate) binding studies on samples of known Diego phenotypes that the expression of the $\mathrm{Di}^{\mathrm{a}}$ antigen is associated with an increased susceptibility of band 3 to labeling 
by H DIDS. This provided evidence for a link between the expression of the $\mathrm{Di}^{\mathrm{a}}$ antigen and the presence of band 3 variant Memphis (45).

DNA sequence analysis (47) showed that the $D i^{a} / D i^{b}$ polymorphism results from a point mutation at nucleotide $2561(\mathrm{C}>\mathrm{T})$ resulting in a single amino acid substitution in position 854 , with a proline corresponding to the $\mathrm{Di}^{\mathrm{b}}$ antigen and leucine to the $\mathrm{Di}^{\mathrm{a}}$ antigen. Molecular analysis of band 3 from individuals with red cells expressing the $\mathrm{Di}^{\mathrm{a}}$ antigen showed the simultaneous occurrence of the mutations $2561 \mathrm{~T}$ (854Leu) and 166G (56Glu) responsible for the Band 3 variant Memphis (47).

Carries of band 3-Memphis are asymptomatic and show no morphologic abnormalities of their erythrocytes (48). Studies to determine the frequencies of band 3-Memphis in some populations have been performed, proving that band 3-Memphis is not a rare polymorphism and that the gene frequency of band 3-Memphis varies among different populations, with a high frequency among Indians and the Japanese (48-51).

Bruce et al. (1995) also reported that the $W r^{a} / W r^{b}$ polymorphism results from a glutamic acid in position 658 of band 3 corresponding to $\mathrm{Wr}^{\mathrm{b}}$ and a lysine in the same position, corresponding to $\mathrm{Wr}^{\mathrm{a}}(52)$.

Evidence suggests that the $\mathrm{Wr}^{\mathrm{b}}$ antigen is also associated with the glycophorin A (GPA) because $\mathrm{Wr}^{\mathrm{b}}$ antigen requires both band 3 and GPA for it's expression in the red cell membrane (52-54).

The recognition that band 3 carries antigens of the Diego blood group system and the elucidation of the $D i^{a} / D i^{b}$ and $W r^{a} / W r^{b}$ polymorphisms have led several investigators to elucidate the molecular basis of the other low incidence Diego antigens and to create a more accurate structural model of band 3 (55).

New studies with band 3 and Diego are being developing and new findings are emerging. We have found in our population by molecular studies a high frequency of 166G mutations (Memphis) and the possibility that the $\mathrm{Di}^{\mathrm{a}}$ antigen can not be associated with the band 3 variant Memphis (56).
In the 1980s and 1990s, serological, biochemical and molecular studies have given a new face to Immuno-hematology. Most of the papers published are cooperative works and are improving the understanding of the Diego system. It is important that these studies should continue in different populations to expand the knowledge of the structure and function of band 3 .

\section{A história do sistema de grupos sangüíneos Diego}

\section{Pedro C. Junqueira, Lilian Castilho}

\section{Resumo}

O sistema de grupos sangüineos Diego, devido à sua raridade, era considerado um fator privado familiar. Investigaçôes posteriores, de estudos familiares na Venezuela e em índios do continente americano e mongóis na Ásia, evidenciaram a sua existência.

Neste relato apresentamos o desenvolvimento do conbecimento e da sua história.

Rev.bras.hematol.hemoter.,2002,24(1):15-23

Palavras-chave: Diego, grupos sangüineos, bistória

\section{References}

1. Levine P, Koch EA, McGee RT. Rare human isoagglutinins and their identification.

Am. J. Clin. Path. 1954; 24: 292-304.

2. Layrisse M, Arends T, Domingues Sisico R. Nuevo grupo sanguíneo encontrado en descendents de indios. Acta Med. Venezuelana 1955; 3: 132-138.

3. Junqueira PC, Wishart PJ, Ottensosser F, Pasqualin R, Lorenso FP, Kalmus H. The Diego blood factor in Brazilian Indians. Nature. 1956; 177:41.

4. Levine P, Robinson EA, Layrisse M, Arends T, Dominguez Sisico R. The Diego blood factor in Brazilian Indians. Nature 1956; 177:40-41. 
5. Layrisse M, Arends T. The Diego blood factor in Chinese and Japanese. Nature. 1956; 177: 1083-1084.

6. Arends T and Layrisse M. Investigación del factor Diego en Japaneses y Chinos. Acta Cientif Venez. 1956; 7:11-12.

7. Lewis M, Ayukawa H, Chown B, Levine P. The blood group antigen Diego in North American Indians and in Japanese. Nature 1956; 177:41.

8. Levine P, Robinson EAV. Some observations of the new buman blood factor $D i^{a}$,

Blood. 1957; 12: 448-453.

9. Layrisse M, Sangger R, Race RR. The inheritance of the antigen Diego: evidence for its independence of other blood group systems. Am. J. Hum. Genet. 1959; 11: 17-25.

10. Layrisse M, Arends T. The Diego blood factor in Negroid populations. Nature. 1957; 178: 478-479.

11. Loureiro Fernandes J, Junqueira PC, Kalmus H, Ottensooser F, Pasqualin R, Wishart P. P.T.C. threshold, color vision and blood factors of Brazilian Indians - Kaingaques.

An. Human Genetics. 1957; 22: 16-21.

12. Junqueira P C, Kalmus H, Wishart P. P.T.C. threshold, color vision and blood factors of Brazilian Indians - Carajas. An. Human Genetics 1957; 22: 22-25

13. Lewis M, Kaita H, Chown B. The blood groups of the Japanese population. An. J. Human Genetics 1957; 9: 274-283.

14. Furuhata T, Yokoyama M, Kuniyuki M. First investigation of the Diego factor in Japanese in Japan, in Tokyo. Proc. Jap. Acad. 1957; 33: 228.

15. Ueno N, Murahato M. Introduction to the Diego blood group and the frequency of the Diego Antigen among Japanese in Kumamoto area. Blood and Transfusion 1957; 4: 146 (in Japanese).

16. Iseki S, Masaki S, Furukawa K, Mohn JF, Lambert RM and Rosamilia HG. Diego and Miltenberger blood factor in Japanese. $\mathbf{J}$. Med. Sci 1958; 2: 120-126.

17. Layrisse M. Anthropological considerations of the Diego (Di) antigen possible application in the studies of Mongolian and bybrid population. Am. J. Phys. Anthropol. 1958; 16: 173-86.

18. Gershowitz H. The Diego factor among Asiatic Indians, Apaches and West African Negroes; blood types of Asiatic Indians and Apaches. Am. J. Phys. Anthropol. 1959; 17: 195-200.

19. Masakis S, Furukawa K. The frequency of the Diego factor in 500 Japanese living in the Jumma area. Jap. J. Legal Med. 1959; 13(3): 359.

20. Salazar Mallen M, Arias T. Inberitance of Diego blood group in Mexican Indians. Science 1959; 130: 164-5.

21. Yokoyama M, Murakata M, Ueno N. The Diego factor in Japanese. Nature 1960: 591.

22. Won CD, Shin HS, Kem SW, Swanson J, Matson GA. Distribution of beredity blood factors among Koreans residing in Seoul, Korea. Am. J. Phys. Anthropol. 1960; 18: $115-124$

23. Layrisse M, Wilbert J. El antigeno del sistema sanguineo Diego. La Fundacion Creole y la Fundacion Eugenio Mendonza; Editora Sucre, Caracas, 1960.

24. Allen FH, Corcoran PA. Blood groups of the Penobscot Indians. Am. J. Phys. Anthropol. 1960; 18: 109-114.

25. Neal JV, Salzano F M, Junqueira P C, Keiter $\mathrm{F}$ and Maybury Lewis D. Studies on the Xavante Indians of the Brazilian Mato Grosso. Human Genetics 1964; 16: 52-140.

26. Tsuchiya T, Kurata M, Fukuma A, Onishi T, Yokoyama M, Kobayashi $\mathrm{H}$ and Tomita K. Anthropological observation of blood groups in Hiroshima. Nature 1964; 204-87.

27. Murakami S. The rare blood types and variants in Japanese. Acta Crim. Jap. 1967; 33: $138-145$.

28. Gershowitz H, Junqueira PC, Salzano FM, Neel JV. Further studies on the Xavante Indians III blood groups and ABH-Le secretor types in the Simoes Lopes and São Marcos Xavantes. Human Genetics 1967; 19: 502-513.

29. Cerqueira AJB, Junqueira PC, Tsum T. Groupos sangüineos dos sistemas ABO, Rh $e$ Diego em Japaneses. A Folha Médic 1968; 57: 105-109.

30. Simmons RT, Albrey JA, Morgan JAG, Smith 
AJ. The Diego blood group: anti-Di $i^{a}$ and Di $(a+)$ blood group antigen found in Caucasians. Med. J. Aust. 1968; 1: 406-7.

31. Cann HM, VanWest B, Barnett CR. Genetics of Diego blood groups in Guatemalan Indians: use of anti-serum to Diego $a$ and Diego b antigens. Science 1968; 162: 1391-2.

32. Iseki S, Masaki S, Furukawa K, Lambert RM and Mohn JF. The blood group antigen $D i^{\underline{a}}$ in Japanese and its independence of the ABH secretor system.

Vox Sang. 1970; 19: 483-7.

33. Nakajima H, Hayakawa Z, Ito H. A new example of anti-Di $i^{a}$ found in Japanese woman.

Vox Sang. 1971; 20: 271-3.

34. Simmons RT. The apparent absence of the Diego (Di $\left.i^{\underline{a}}\right)$ and the Wright (Wr $\left.{ }^{\underline{a}}\right)$ blood group antigens in Australian aborigines and in Guineans. Vox Sang. 1979; 19: 533-6.

35. Edwards, Moulds JM, Alperin JB. Studies of the Diego blood group among Mexican Indians. Transfusion 1986; 26: 234-6.

36. Leon S, Mak KH, Chua E. Blood group distribution among Chinese donors in Hong Kong. Presented at the $19^{\text {th }}$ Congress of International Society of Blood Transfusion, in Sidney Australia. May 1986.

37. Lin Chu M, Broadberry RE, Chang FJ. The distribution of blood group antigens and alloantibodies among Chinese in Taiwan. Transfusion 1988; 28: 350-2.

38. Yung $\mathrm{CH}$, Chow MP, Hu Hy, Mon LL, Lyou Jy, Lee TD. Blood group phenotypes in Taiwan. Transfusion 1989; 29: 233-5.

39. Lee TD, Zhad TM, Chow MP and Lee G. HLA, GM, KM and Diego blood group typing of Chippewa Indians. Transfusion 1990; 30: 728-732.

40. Mourant AE, Kopec AC, Domanicewska, Sobezak K, eds. Distribution of the buman blood groups and other polymorphisms. London: Oxford University Press 1976: 608-14.

41. Thompson PR, Childers DM, Hatcher DE. Anti-D ${ }^{b}$-first and second examples. Vox Sang 1967; 13:314-318.

42. Race RR, Sanger R. Blood Groups in Man, $6^{\text {th }}$ edn. Oxford: Blackwell Scientific
Publications, 1975.

43. Zago-Novaretti MC, Soares MOC, DorlhiacLlacer PE, Chamone DAF. Anti-Diego in multitransfused patients. Rev. Paulista Med. 1992;110 (S):IH52.

44. Daniels GL, Anstee DJ, Cartron JP, Dahr W, Fletcher A, Garratty G, Henry S, Jorgensen J, Judd WJ, Kornstad L, Levene C, Lin M, Lomas-Francis C, Lubenko A, Moulds JJ, Moulds JM, Overbeeke M, Reid Me, Rouger P, Scott M, Sistonen P, Smart E, Tani Y, Wendel S, Zelinski T. International Society of Blood Transfusion working party on terminology for red cell surface antigens. Vox Sang 2001;80:193-196.

45. Spring FA, Bruce LJ, Anstee DJ, Tanner MJA. $A$ red cell band 3 variant with altered stilbene disulphonate binding is associated with the Diego (Di $\left.{ }^{a}\right)$ blood group antigen. Biochem J 1992; 288:713-716.

46. Zelinski T, Coghlan G, White L, Philips S. Provisional assignment of the Diego blood group locus to chromosome 17. Transfusion 1993, 33 (Suppl.1)47S: Abstract.

47. Bruce LJ, Anstee DJ, Spring FA, Tanner MJA. Band 3 Memphis variant II. Altered stilbene disulphonate binding and the Diego (Di ${ }^{a}$ ) blood group antigen are associated with the buman erythrocyte band 3 mutation PrO $_{854} \rightarrow$ Leu. J. Biol. Chem. 1994a; 269:16155-16158.

48. Ranney HM, Rosemberg GH, Morrison M, Mueller TJ. Frequencies of band 3 variants of human red cell membranes in some different populations. Br. J. Haematol. 1990; 75:262-267.

49. Ideguchi H, Okubo K, Ishikawa A, Futata Y, Hamasaki N. Band 3-Memphis is associated with a lower transport rate of phosphoenolpyrovate. Br. J. Haematol. 1992; 82:122-125.

50. Mueller TJ, Morrison M. Detection of $a$ variant of protein 3, the major transmembrane protein of buman erythrocyte. J. Biol. Chem.. 1977; 252: 65736576.

51. Palatnik M, da Silva Simoes MLM, Alves ZMS, Laranjeira NSM. The 60 and $63 \mathrm{kDa}$ proteolytic peptides of the red cell membrane 
band 3-protein: their prevalence in human and non buman primates. Hum. Genet. 1990; 86:126-130.

52. Bruce LJ, Ring SM, Anstee DJ, Reid ME, Wilkinson S, Tanner MJA. Changes in the blood group Wright antigens are associated with a mutation at amino acid 658 in buman erythrocyte band 3: A site of interaction between band 3 and glycophorin A under certain conditions. Blood 1995; 85:541-547.

53. Ring SM, Tippet P, Swallow DM. Comparative immunochemical analysis of $\mathrm{Wr}^{a}$ and $\mathrm{Wr}^{b}$ red cell antigens. Vox Sang. 1994; 67:226-230.

54. Telen MJ, Chasis JA. Relationship of the buman erytbrocyte $\mathrm{Wr}^{b}$ antigen to an interaction between glycophorin A and band 3. Blood 1990; 76:842-848.

55. Jarolim P, Rubin HL, Zakova D, Storry J, Reid ME. Characterization of seven low incidence blood group antigens carried by erythrocyte band 3 protein. Blood 1998; 92:4836-4843.

56. Balleotti Jr W, Rios M, Fabron A, Costa FF, Bianco C. Castilho L. Frequency of the DIA/ Memphis II allele among Amazonian Indians, Brazilians of Japanese descent and Brazilians blood donors. Transfusion 2000; 39(S).

Recebido: 28/06/01

Aceito: 13/02/02 